\title{
Research Paper \\ The Effect of 10 Weeks Core Muscle Training on Levels of Follistatin, Myostatin, and Pain in Elderly Women
}

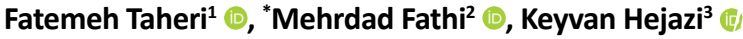

1. Department of Sport Physiology, Faculty of Sport Sciences, Bojnourd Branch, Islamic Azad University, Bojnourd, Iran.

2. Department of Sport Physiology, Faculty of Sport Sciences, Ferdowsi University of Mashhad, Mashhad, Iran.

3. Department of Sport Physiology, Faculty of Sport Sciences, Hakim Sabzevari University, Sabzevar, Iran.

\begin{tabular}{c|l}
$\begin{array}{c}\text { Use your device to scan } \\
\text { and read the article online }\end{array}$ & $\begin{array}{l}\text { Crtation Taheri F, Fathi M, Hejazi K. [The Effect of 10 Weeks Core Muscle Training on Levels of Follistatin, Myostatin, and Pain } \\
\text { in Elderly Women (Persian)]. Quarterly of "The Horizon of Medical Sciences". 2021; 27(2):164-181. https://doi.org/10.32598/ } \\
\text { hms.27.2.1970.12 }\end{array}$ \\
dolihttps://doi.org/10.32598/hms.27.2.1970.12
\end{tabular}

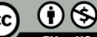

Received: 17 Sep 2020 Accepted: 30 Oct 2020 Available Online: 01 Apr 2021

Keywords: Low back pain, Aged Follistatin, Myostatin

\section{A B S TRACT}

Aims Structural postural changes due to aging are common among the elderly due to decreased muscle mass and tissue. We evaluated the effect of 10 weeks of core muscle training on serum levels of follistatin, myostatin, and pain in older women with low back pain.

Methods \& Materials A total of 18 older women with low back pain (aged 60 to 70 y) were randomly assigned into two groups: experimental $(n=9)$ and control $(n=9)$. The training program of core muscles included 55 to 60 min sessions, 3 times per week for 10 weeks. Before and after the training, serum follistatin and myostatin, along with pain intensity and lumbar function, were evaluated. The obtained data were analyzed by paired sample $t$ test and Analysis of Covariance (ANCOVA) to compare intragroup and intergroup differences, respectively.

Findings Core muscle training led to a significant reduction in the relative pain scale $(P=0.001)$. Follistatin $(P=0.001)$ and myostatin $(P=0.001)$ levels increased and decreased significantly at the end of the training period, respectively. Lumbar function improved in the training group. Changes in means of between groups in relative pain scale, follistatin, myostatin, and lumbar function have a significant difference $(\mathrm{P}<0.05)$.

Conclusion Core muscle training was associated with a decline in myostatin level, increase in follistatin level, and improving lumbar function. In summary, core muscle training may decrease muscle atrophy related to age.

\section{English Version}

\section{Introduction}

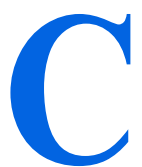

hanges in skeletal muscle mass are among the inevitable old age problems and are associated with progressive skeletal, muscular weakness [1]. Because of the growth of the elderly population, loss of body mass and tissue has become significantly more prevalent, which is one of the structural-postural changes due to aging [2]. If muscle mass begins to decline, symptoms of decreased functional independence and back pain will gradually increase with age. This decreasing trend is intensified by having bad habits [3, 4]. However, improving lifestyle such as following a proper diet and exercising are solid and appropriate ways to deal with this erosive process $[2,5]$. Many studies have examined muscle changes that occur with age.

\section{Corresponding Author:}

Mehrdad Fathi, PhD.

Address: Department of Sport Physiology, Faculty of Sport Sciences, Ferdowsi University of Mashhad, Mashhad, Iran.

Tel: +98 (51) 38833910

E-mail: mfathei@um.ac.ir 
These studies have found that aging is associated with an increase in atrophy and muscle weakness of the lower extremities more than the upper extremities [6]. Also, there is an inverse relationship between aging and the size of the muscles of the central part of the body (abdomen and back) [7].

On the other hand, several studies have shown that muscle weakness is associated with musculoskeletal pain, such as back pain [8]. Because with increasing age, the muscles of the central part of the body, such as the multifidus muscle, become weak and atrophic, and this weakness can cause Low Back Pain (LBP) [9]. Therefore, the decrease in muscle mass during the aging process is an indirect but very influential factor in causing LBP [8]. Besides, losing muscle mass is associated with a decrease in physical function of the elderly, which affects their quality of life $[2,10]$.

Myostatin is a secretory factor and a member of a large family of secretory growth factors and has a critical negative regulatory role in skeletal muscle growth and homeostasis, which is secreted into the bloodstream as an endocrine agent after expression in skeletal muscle. Myostatin exerts its inhibitory effect (inhibition of proliferation and differentiation of satellite cells) on the surface of muscle cells by binding to the activin receptor and ultimately reducing muscle mass [11]. It has been observed that the expression of myostatin increases during periods of inactivity, and also the inhibition of serum myostatin leads to an increase in strength and muscle mass [12].

Another factor related to muscle mass that can be mentioned is follistatin. It is a single-chain polypeptide with diverse functions and is a member of the large family of growth factor-beta, the largest family of secreted growth factors, differentiation, and homeostasis of the body. This family plays a significant role in regulating and promoting the growth of body tissues [13]. Essential roles of follistatin include neutralizing the actions of growth factor-beta transporter proteins, including myostatin, tissue growth and differentiation, and regeneration and repair of damaged tissues [13].

Recent research has shown that various exercises can increase follistatin and reduce myostatin [14]. Santos et al. examined the effect of eight weeks of resistance training in different ways (including high and low-intensity squats) on the expression of myostatin gene inhibitors in active men. The subjects were grouped in strength training, resistance training, and controls. The researchers concluded that the expression of myostatin signaling pathway inhibitors was increased [15]. Yarahmadi et al. evaluated the effectiveness of core stability exercises on functional disability, dynamic balance, and lumbar-pelvic proprioception in patients with non-specific chronic LBP and concluded that a significant improvement was observed in functional disability, dynamic balance, and proprioception of the core stability of the exercise group [16]. By examining the effect of 6 to 12 weeks of core stability training on the lumbar joint position sense in 38 patients with LBP, Pantoma et al. concluded that core stability training improved the sense of lumbar joint position and reduced pain and functional disability [17]. Rastegar Moghaddam et al. reported that performing 10 weeks of core stability exercises significantly increased the longitudinal and transverse cross-sectional areas of the multifidus muscle. On the other hand, the subjects' level of pain in the group of core stability exercises in the fifth and tenth weeks compared to the beginning of the intervention was significantly reduced [18]. After studying the effect of eight weeks of elastic band resistance training on serum myostatin and body composition of 26 older women, Vatankhah Khozani et al. concluded that the training significantly reduced the percentage of fat and myostatin level in the intervention group compared to the control group [19].

In summary, very little research has been done on the different forms of exercise, and which exercise method can have the most positive effects on the follistatin and myostatin factors. Regarding the effects of different training methods, especially core stability training exercises, there are still ambiguities about how these exercises affect physiological factors such as follistatin and myostatin. Different exercises can have various effects on the ratio of follistatin to myostatin, anaerobic function, and fatigue index. However, no research has investigated the difference between core stability training exercises on these indicators. Thus, we decided to answer whether core muscle training exercises affect serum follistatin and myostatin, as well as the pain in women with chronic LBP. Therefore, the present study aimed to evaluate the effect of 10 weeks of core muscle training on the levels of follistatin, serum myostatin, and pain in women with chronic LBP.

\section{Materials and Methods}

This research is a quasi-experimental study in which the experimental and control groups were compared with pre-test and post-test. The study population includes older women over 60 years (age range between 60 and 70 years) with chronic low back pain selected by the available and purposive sampling method. In the first stage, women were introduced to the nature and manner of cooperation with the study procedure. The inclusion criteria included chronic low back pain (more than 3 months), age over 55 years, body mass index between 25 and $30 \mathrm{~kg} / \mathrm{m}^{2}$. The exclusion criteria included pregnancy, specific spinal abnormalities (spondylolysis or spondylolisthesis), lumbar scoliosis with 
an angle of more than 10 degrees, severe osteoarthritis of the knee, and severely debilitating diseases. Subjects voluntarily participated in the research based on the study conditions and consciously signed the consent form. The samples were then randomly divided into experimental $(n=9)$ and control $(\mathrm{n}=9)$ groups.

To evaluate the body composition, we measured the subjects' height with Seka height meter (made in Germany) with 5-mm precision accuracy. Their hips and waist circumferences were measured with a tape measure (Mabis, Japan) with 5-mm precision accuracy. Finally, we measured their body fat percentage and weight with a precision accuracy of $100 \mathrm{~g}$ using a bioelectrical impedance device (model InBody_720/South Korea).

All measurements were performed while the subjects had abstained from eating and drinking four hours before the test. So their bladder, stomach, and intestines were empty as much as possible. The subjects were allowed to enter the project after cardiovascular examination, blood pressure measurement, and electrocardiogram registration by a specialist physician.

In this study, the numerical version of the Visual Analog Scale (VAS) was used to estimate the subjects' pain intensity [20]. On the VAS, a horizontal line $100 \mathrm{~mm}$ long is presented with two extremes of painless (left) and severe pain (right) on either side of the line. Based on these two extremes, the person marks his pain status on the line. The amount of pain is calculated in millimeters. The interpretation of data obtained from VAS is as follows: the numbers $0-4 \mathrm{~mm}$ are painless, $5-44 \mathrm{~mm}$ is mild pain, $45-74 \mathrm{~mm}$ is moderate pain, and 75-100 mm indicates severe pain [20].

The Back Performance Scale (BPS) was assessed by a 15-point scale (Borg 6-20 points) (five tests). The tests on this scale included wearing socks, picking up paper from the floor, getting out of bed, leaning forward, and lifting a box. Each test had four answers, from simple (zero points) to difficult (3 points). In the test of the wearing sock, the person sits on a high bench so that her feet did not touch the ground. Then, he was asked to raise his feet to her abdomen by bending the knee and grasp the toes with both hands. In the test of picking paper from the ground, a person in a standing position was asked to remove the paper placed on the ground before her. In the getting out of the bed test, the person is asked to lay down and then sit without using her hands. In the leaning forward test, the person should stand with straight knees $10 \mathrm{~cm}$ apart and is asked to bring the hands as close to the ground as possible without bending the knees. In the box lifting test, the person should stand before the table with a height of approximately $76 \mathrm{~cm}$ and place a box weighing $5 \mathrm{~kg}$ on the floor and back on the table for 1 minute. Then, the number of repetitions was recorded. The maximum score was 15 and represented the person's worst lumbar function, and the minimum score was zero, which represents the best lumbar function.

The exercise activity protocol was also implemented for 10 weeks and included eight types of core ground muscle exercises focusing on isotonic and isometric strengthening of the lumbar and multifidus muscle [18] (Figure 1).

The core muscle exercises were as follows: A, Boat or contraction of the back muscles, without leaning on a chair, B: Deep breathing with chest muscle stretching and contraction of the back muscles without leaning on a chair, $\mathrm{C}$ : Isometric contraction in the muscles that open the waist, D: corrected crunches and sit-ups E: Bridge movement, F: lumber extension when lying on the stomach, G: Shoulder flexion and static strengthening of the muscles that stabilize the spine, H: Thigh flexion, In all exercises, remind the subject not to hold her breath and talk to the subjects constantly.

In this study, blood samples were collected 48 hours before the training session and 48 hours after it. The Sampling was performed between 6 and $7 \mathrm{AM}$ after 8 to 10 hours of fasting. About $5 \mathrm{~mL}$ of blood were taken from the vein of the subject's left hand in a sitting position and at rest.

To determine the amount of follistatin and myostatin, we used the ELISA method and laboratory kit of follistatin and myostatin (CUSABIO Japan).

The collected data were analyzed by SPSS version 21 . After ensuring the normality of the data distribution using the Shapiro-Wilk test and homogeneity of variances by Levene's test, the correlated t test and Analysis of Covariance (ANCOVA) were used to compare intragroup and intergroup changes, respectively. The significance level was considered less than 0.05 .

\section{Results}

The characteristics of the experimental and control groups are shown in Table 1. Table 2 shows that the changes of intragroup variables of weight $(\mathrm{P}=0.1)$, body mass index $(\mathrm{P}=0.9)$, body fat percentage $(\mathrm{P}=0.5)$, skeletal muscle mass $(\mathrm{P}=0.8)$ did not change significantly at the end of the training period. The relative pain scale $(\mathrm{P}=0.001)$ was significantly reduced. Follistatin $(\mathrm{P}=0.001)$ and myostatin $(\mathrm{P}=0.001)$ levels increased and decreased significantly at the end of the training period, respectively. But in the control group, these changes were not significant $(\mathrm{P}>0.05)$. There was a significant difference between the experimental and control 
A

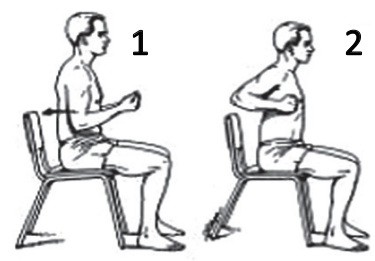

B

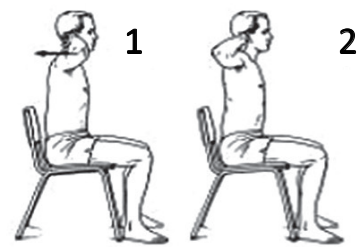

2

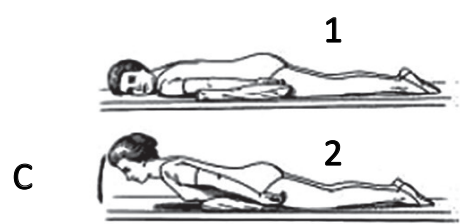

3

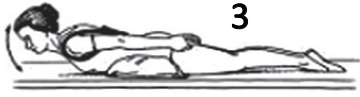

E

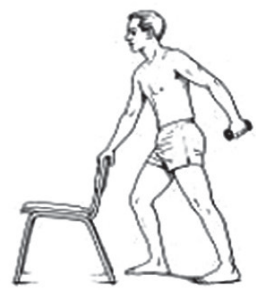

2

F

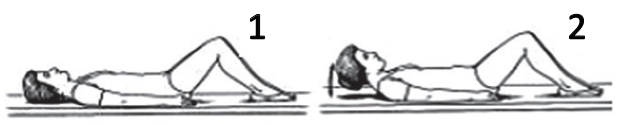

S
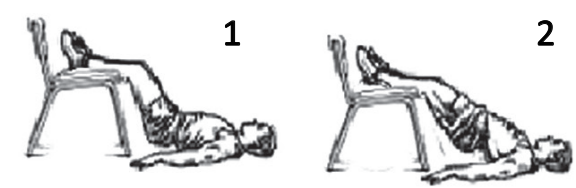

2

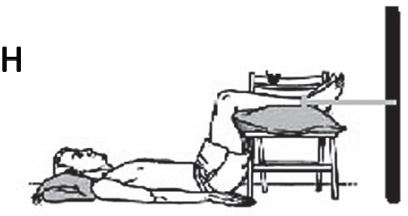

Quarterly of

The Horizon of Medical Sciences

Figure 1. Core stability exercises

groups in the intergroup mean variables regarding relative pain scale, serum follistatin, and myostatin $(\mathrm{P}<0.05)$.

The changes in the intragroup means in the tests of rising from the bed ( $\mathrm{P}=0.03)$, bringing the fingers to the ground $(\mathrm{P}=0.03)$, lifting the box $(\mathrm{P}=0.04)$, and the total score of lumbar function scales of women with chronic LBP decreased significantly at the end of the study period $(\mathrm{P}=0.02)$ (Table 3). Changes in mean intergroup variables in the tests of wearing socks, getting out of bed, bringing fingers to the ground, lifting the box, and total score of lumbar function scales are significantly different between the experimental and control group $(\mathrm{P}<0.05)$.

\section{Discussion}

This study aimed to evaluate the effect of 10 weeks of core muscle training on the levels of follistatin, serum myostatin, and pain in women with chronic LBP. The present study results showed that core muscle training led to a significant increase in follistatin levels and a significant decrease in se- rum myostatin. Hoffman et al. also reported that three to six months of resistance training and elastic band training with dietary supplementation improved exercise performance and increased follistatin, decreased the ratio of follistatin to activin $\mathrm{A}$, and did not significantly alter myostatin levels [21]. In the study of follistatin changes, the muscle's anabolic response is consistent with previous studies [22, 23]. In other words, due to anabolic resistance and disruption of muscle anabolic signaling pathways, the muscles of the elderly do not respond like the muscles of young people to protein supplements and require more time and protein consumption [22]. More than $80 \%$ of protein synthesis after food intake is related to protein consumption and amino acids play an essential role in this process [24]. Follistatin is a positive regulator of muscle growth factor, and various studies have been performed to evaluate changes in this hormone in response to exercise.

After exercise, the levels of activin-follistatin gene expression in rat liver change, and activin mRNA levels decrease [25]. In general, few studies have examined 
Table 1. Anthropometric characteristics of women with chronic low back pain

\begin{tabular}{|c|c|c|c|c|c|}
\hline \multirow{2}{*}{ Groups } & \multicolumn{5}{|c|}{ Variables (Mean \pm SD) } \\
\hline & Age (y) & Height (cm) & Weight (kg) & Body Mass Index $\left(\mathrm{kg} / \mathrm{m}^{2}\right)$ & Percentage of Body Fat (\%) \\
\hline Experimental (9 women) & $68.83 \pm 2.22$ & $161.46 \pm 3.64$ & $66.4 \pm 4.53$ & $25.6 \pm 4.8$ & $33.8 \pm 8.7$ \\
\hline Control (9 women) & $69.54 \pm 3.85$ & $161.21 \pm 2.63$ & $66.59 \pm 2.32$ & $25.68 \pm 3.52$ & $33.59 \pm 5.6$ \\
\hline
\end{tabular}

muscle hypertrophy markers in response to core stability exercises in older women with LBP. The cellular and molecular mechanisms that transmit cellular signals, followed by muscle growth, are not yet fully disclosed. Exerciseinduced muscle contraction is the process of converting a mechanical signal into a series of molecular events. These molecules regulate gene expression, protein synthesis, and protein breakdown by activating specific signaling pathways that include primary and secondary messengers, followed by muscle cell adaptation [26]. Primary messengers who initiate cascading processes include calcium current, redox potential, stretching, phosphorylation potential, and mechanical tensions. Muscle tension alone and independent of the increase in contractile activity can also stimulate protein synthesis through several pathways. Extracellular matrix stretching activates intracellular signals, leading to changes in gene expression and protein synthesis [27]. According to the results of the present study and previous studies, core stability training by balancing the positive and negative regulators of muscle growth can play a role in improving the physical condition of the elderly. By the decline of muscle growth regulators in old age, the inhibitory role

Table 2. Variation of body composition, relative pain scale, and follistatin and myostatin levels in elderly women

\begin{tabular}{|c|c|c|c|c|c|c|c|}
\hline \multirow{3}{*}{ Variables } & \multirow{3}{*}{ Groups } & \multicolumn{2}{|c|}{ Mean $\pm S D$} & \multicolumn{4}{|c|}{ Changes } \\
\hline & & \multirow{2}{*}{ Pre-test } & \multirow{2}{*}{ Post-test } & \multicolumn{2}{|c|}{ Within the Group } & \multicolumn{2}{|c|}{ Between Groups } \\
\hline & & & & $\mathbf{t}$ & $\mathbf{P}$ & $t$ & $\mathbf{P}$ \\
\hline \multirow{2}{*}{ Weight (kg) } & Experimental & $66.4 \pm 4.53$ & $66.68 \pm 4.92$ & 1.00 & 0.1 & \multirow{2}{*}{0.17} & \multirow{2}{*}{0.86} \\
\hline & Control & $66.59 \pm 2.32$ & $66.61 \pm 1.87$ & 1.77 & 0.11 & & \\
\hline \multirow{2}{*}{ Body mass index $\left(\mathrm{kg} / \mathrm{m}^{2}\right)$} & Experimental & $25.6 \pm 4.8$ & $26.1 \pm 3.9$ & 0.114 & 0.9 & \multirow{2}{*}{-1.3} & \multirow{2}{*}{0.2} \\
\hline & Control & $25.68 \pm 3.52$ & $25.59 \pm 2.34$ & 0.466 & 0.65 & & \\
\hline \multirow{2}{*}{ Percentage of body fat (\%) } & Experimental & $33.8 \pm 8.7$ & $33.06 \pm 8.4$ & 0.6 & 0.5 & \multirow{2}{*}{2.0} & \multirow{2}{*}{0.56} \\
\hline & Control & $33.59 \pm 5.6$ & $33.63 \pm 5.7$ & -0.68 & 0.51 & & \\
\hline \multirow{2}{*}{ Skeletal muscle mass (\%) } & Experimental & $28.36 \pm 3.9$ & $29.2 \pm 1.98$ & 0.1 & 0.8 & \multirow{2}{*}{1.15} & \multirow{2}{*}{0.26} \\
\hline & Control & $28.23 \pm 2.3$ & $28.1 \pm 2.32$ & -0.13 & 0.89 & & \\
\hline \multirow{2}{*}{ Relative scale of pain (Score) } & Experimental & $6.5 \pm 1.378$ & $2.92 \pm 1.98$ & -4.9 & $0.001^{+}$ & \multirow{2}{*}{-3.7} & \multirow{2}{*}{$0.002^{+}$} \\
\hline & Control & $6.39 \pm 1.11$ & $6.57 \pm 1.00$ & -0.14 & 0.89 & & \\
\hline \multirow{2}{*}{ Follistatin (ng/mL) } & Experimental & $27.8 \pm 3.6$ & $63.8 \pm 6.4$ & 14.2 & $0.001^{\dagger}$ & \multirow{2}{*}{10.32} & \multirow{2}{*}{$0.001^{\dagger}$} \\
\hline & Control & $28.1 \pm 5.2$ & $30.5 \pm 7.23$ & 0.85 & 0.41 & & \\
\hline \multirow{2}{*}{ Myostatin (ng/mL) } & Experimental & $4.04 \pm 0.15$ & $3.53 \pm 0.29$ & 5.30 & $0.001^{\dagger}$ & \multirow{2}{*}{4.69} & \multirow{2}{*}{$0.001^{\dagger}$} \\
\hline & Control & $4.06 \pm 0.18$ & $4.15 \pm 0.32$ & -1.05 & 0.32 & & \\
\hline
\end{tabular}

†Statistical significance at the level of $\mathrm{P}<0.05$. 
Table 3. Comparison of intragroup and intergroup variance changes in lumbar function subscales of women with chronic low back pain

\begin{tabular}{|c|c|c|c|c|c|c|c|}
\hline \multirow{3}{*}{ Variables } & \multirow{3}{*}{ Groups } & \multicolumn{2}{|c|}{ Mean $\pm S D$} & \multicolumn{4}{|c|}{ Changes } \\
\hline & & \multirow[t]{2}{*}{ Pre-test } & \multirow[t]{2}{*}{ Post-test } & \multicolumn{2}{|c|}{ Within the Group } & \multicolumn{2}{|c|}{ Between Groups } \\
\hline & & & & $\mathbf{t}$ & $\mathbf{P}$ & $\mathbf{t}$ & $\mathbf{P}$ \\
\hline \multirow{2}{*}{ Test of wearing socks } & Experimental & $1.5 \pm 1.04$ & $1.1 \pm 0.83$ & -2.29 & 0.05 & \multirow{2}{*}{-1.00} & \multirow{2}{*}{$0.01^{+}$} \\
\hline & Control & $1.55 \pm 0.94$ & $1.75 \pm 0.9667$ & -0.35 & 0.72 & & \\
\hline \multirow{2}{*}{$\begin{array}{l}\text { Test for removing paper } \\
\text { from the ground }\end{array}$} & Experimental & $1.5 \pm 0.8$ & $1.00 \pm 0.62$ & -1.15 & 0.16 & \multirow{2}{*}{1.64} & \multirow{2}{*}{0.12} \\
\hline & Control & $1.45 \pm 0.6$ & $1.5 \pm 0.51$ & -1.5 & 0.16 & & \\
\hline \multirow{2}{*}{ Get out of bed test } & Experimental & $2.17 \pm 0.98$ & $1.17 \pm 1.1$ & -4.27 & $0.03^{+}$ & \multirow{2}{*}{-2.54} & \multirow{2}{*}{$0.02^{+}$} \\
\hline & Control & $2.0 \pm 0.725$ & $1.95 \pm 0.82$ & 0.8 & 0.44 & & \\
\hline \multirow{2}{*}{$\begin{array}{l}\text { Test to bring the fingers } \\
\text { to the ground }\end{array}$} & Experimental & $1.33 \pm 1.3$ & $0.81 \pm 0.67$ & -4.2 & $0.03^{+}$ & \multirow{2}{*}{-2.13} & \multirow{2}{*}{$0.04^{+}$} \\
\hline & Control & $1.3 \pm 1.031$ & $1.05 \pm 0.51$ & 1.315 & 0.22 & & \\
\hline \multirow{2}{*}{ Box lifting test } & Experimental & $2.33 \pm 0.51$ & $1.5 \pm 0.54$ & 4.00 & $0.04{ }^{\dagger}$ & \multirow{2}{*}{-2.35} & \multirow{2}{*}{$0.03^{+}$} \\
\hline & Control & $2.3 \pm 0.47$ & $2.25 \pm 0.78$ & 0.00 & 1.00 & & \\
\hline \multirow{2}{*}{ Total score (percentage) } & Experimental & $58.5 \pm 15.9$ & $33.3 \pm 13.3$ & 4.64 & $0.02^{+}$ & \multirow{2}{*}{-3.19} & \multirow{2}{*}{$0.01^{+}$} \\
\hline & Control & $53.3 \pm 10.0$ & $50.3 \pm 8.8$ & 0.61 & 0.55 & & \\
\hline
\end{tabular}

'Statistically significance at the level of $\mathrm{P}<0.05$.

of negative regulators, including myostatin, is more prominent [19]. Of course, it is also worth considering that older people have mobility limitations due to the problems created in the physiological and physical condition; therefore, applying the exercise load and maintaining the training duration face limitations that the use of this type of exercise can help these people more. Therefore, this type of training intervention helps rehabilitation and sports programs for the elderly [17].

The present study results showed that core stability exercises lead to a significant reduction in the degree of pain and improved lumbar function in older women with chronic LBP. In the study of chronic LBP changes in older women, the multifidus muscle plays a stabilizing role in the spine and prevents the spine from bending. As we know, multifidus muscle atrophy is associated with low back pain [28]. The multifidus muscle is in a confined anatomical position. It is surrounded on both sides by transverse and shock-absorbing processes, and its volume and hypertrophy can increase only from transverse and superficial directions. This is the reason for the triangular shape of this muscle [29]. The cross-sectional area of the multifidus muscle decreases with age, and if this muscle atrophy is compensated, chronic low back pain in older women can be reduced.
Quarterly of

The Horizon of Medical Sciences
In studying the cause of chronic LBP, several etiologies have been stated, including atrophy, loss of strength, and mass of multifidus muscle due to aging $[28,30]$. Thus, the weakness of abdominal muscles, deep trunk muscles, and lack of proper control of deep trunk muscles such as multifidus muscle are among the main etiologies [31]. Numerous studies have reported a reduction in LBP in response to exercise $[32,33]$. However, the mechanism of this reduction is not well understood. Three theories are proposed to explain the mechanism of pain relief; 1) mechanical theory (increase of core stren $g$ th and stability), 2) neurological theory (desensitization), and 3) acting theory (classified activity) [34]. In all these theories, exercise is a physical or behavioral tool that reduces the severity of pain and disability due to low back pain [34]. In mechanical theory, core stability exercis e was performed for 10 weeks, and only after five weeks, the pain decreases significantly. Also, from the perspective of physiological adaptation to sports activity, neuronal adaptation, which is the first response of the neuromuscular system to sports activity [35], can be responsible for increasing strength and subsequently reducing chronic LBP in older women $[22,36]$. Contradictory results are likely to be due to differences in the participants' physiological conditions, health, duration, type and intensity of exercise, and nutritional status. Since this study had 
many limitations, including various diets, different adaptive responses to physical activity, a small number of subjects due to the withdrawal of some of them from participating in the present study, and individual differences, caution should be observed in interpreting the results.

\section{Conclusion}

In general, core muscle exercises led to a significant reduction in the relative intensity of pain. Follistatin and myostatin levels increased and decreased significantly at the end of the training period, respectively. The low back function also improved in older women with chronic LBP at the end of the training. However, due to the importance of physical activity in preventing and treating many pains, experts recommend exercise counseling to treat chronic back pain. Besides, exercise increases the strength and social participation of older women. Therefore, these interventions are a good treatment for chronic LBP, which is very common, especially among the elderly.

\section{Ethical Considerations}

\section{Compliance with ethical guidelines}

This study was approved by the Ethics Committee of theBojnourd University of Medical Sciences (Code: IR.IAU. BOJNOURD.REC.1395.023).

\section{Funding}

The article was extracted from the MA. thesis of the first author at the Department of Sports Physiology, Faculty of Sports Sciences, Islamic Azad University of Bojnourd.

\section{Authors' contributions}

Implementation of the protocol: Fatemeh Taheri and Mehrdad Fathi; Final approval: All Authors; Conceptualization : Mehrdad Fathi; Data analysis, Writing - original draft, and writing - review \& editing: Keyvan Hejazi.

\section{Conflicts of interest}

The authors declared no conflict of interest. 


\title{
تأثير ده هفته تمرينات عضلات مركزى بر سطوح فوليستاتين، مايوستاتين و ميزان درد زنان سالمند
}

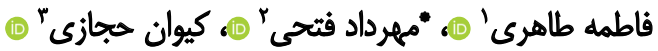

\author{
ا. كروه فيزيولوزى ورزشى، دانشكده علوم ورزشى، واحد بجنورد، دانشكاه آزاد اسلامى، بجنورده، ايران.

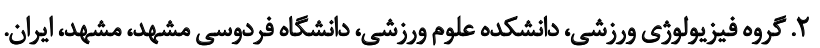

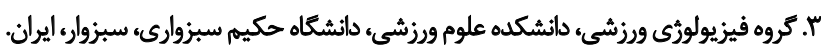

\section{حكبد}

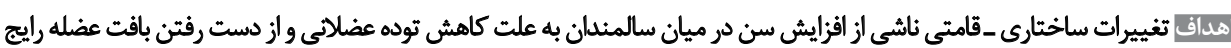

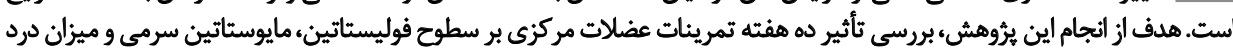

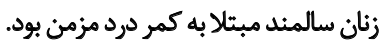

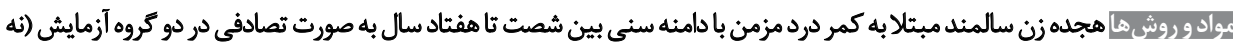

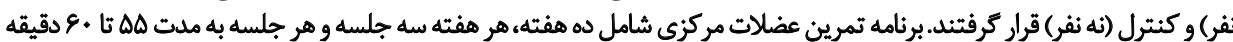

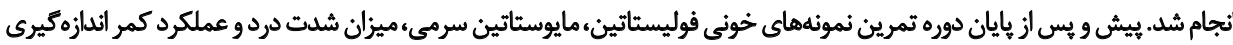

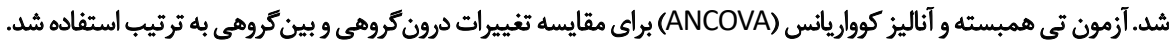

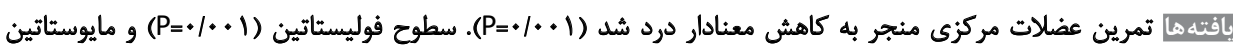

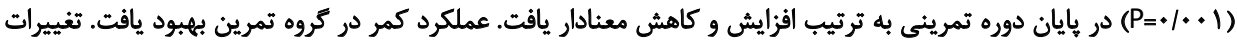

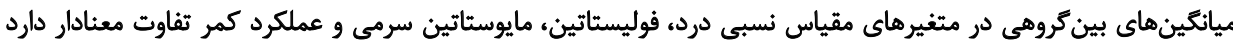

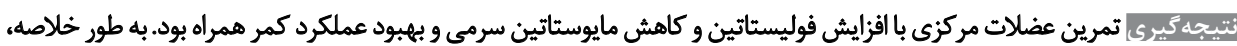

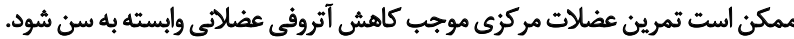

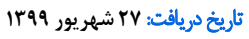

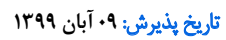

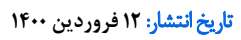

رئيم غذايى مناسب و انجام فعاليت ورزشى، ابزار هاى قوى و مناسبى

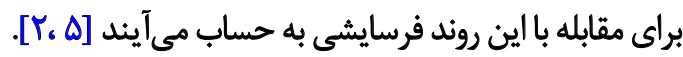

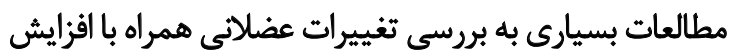

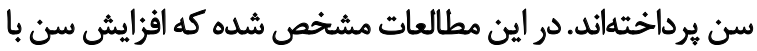
افزايش روند آتروفى و ضعف عضلانى اندام تحتانى بيش از ازندام اندام فوقانى توأم است [ع] أن

همجنين نشان داده شده است كه بين سالمندى و اندازه

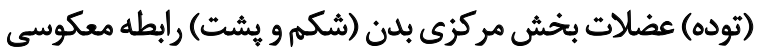

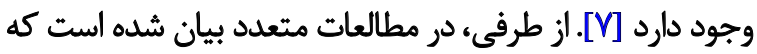

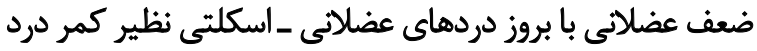

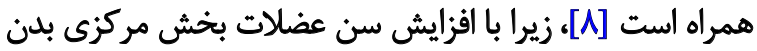

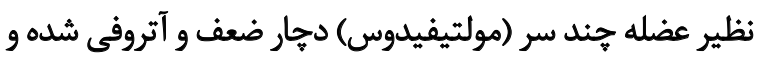

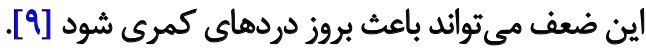

تغييرات توده عضله اسكلتى يكى از مشكلات اجتنابنايذير

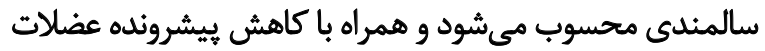

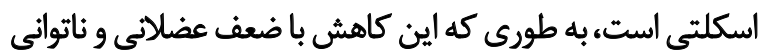

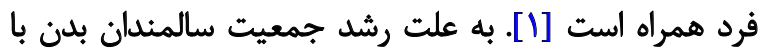

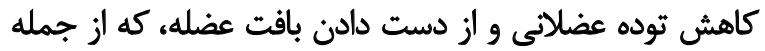

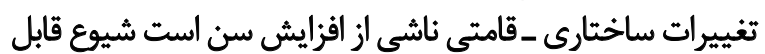

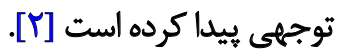
جنانجه توده عضلانى شروع به كاهش كند؛ با افزايش سن،

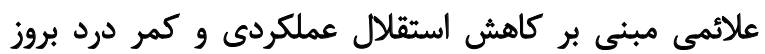

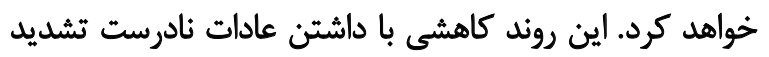

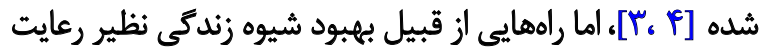


تعادل يويا و حس عمقى گروه تمرينات ثبات مركزى مشاهده

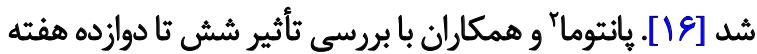

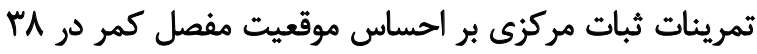

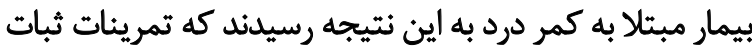

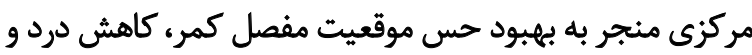

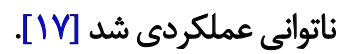

رستكارمقدم و همكاران گَزارش كردند اجراي ده هفته تمرينات

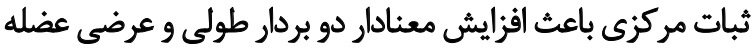

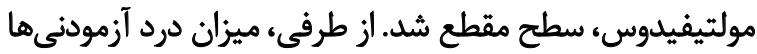

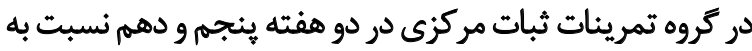
شروع آزمايش به طور معنادارى كاهش يافت [1/]]. وطن خواه خوزاني و همكاران با بررسى تأثير هشت هفته باني

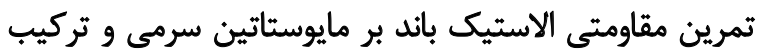

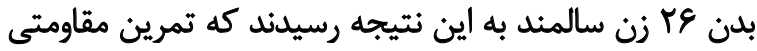

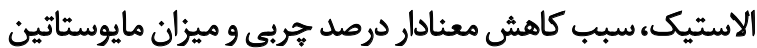

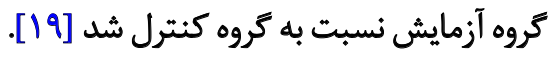

به طور خلاصه، در مورد شيوههاى مختلف ورزشى و اينكه

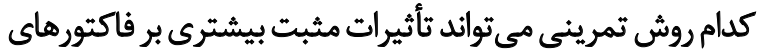

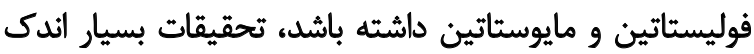

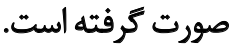

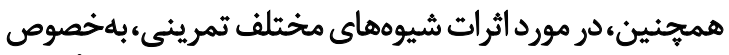

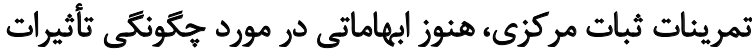

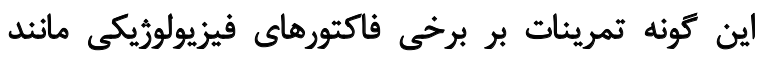
فوليستاتين و مايوستاتين وجود دارد.

با توجه به مطالب ذكرشده و اينكه تمرينات مختلف ورزشى فئي

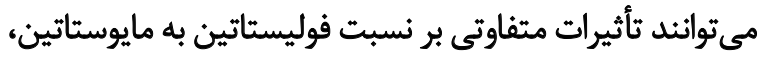

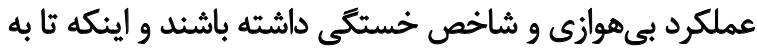

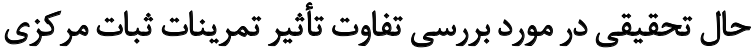

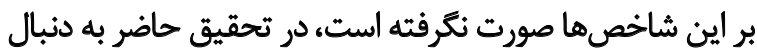
باسخكويى به اين سؤال هستيم كه آيا فعاليت ورزشى تمرئ تمرينات

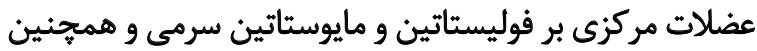
ميزان درد زنان مبتلا به كمر درد مزمن تأثير دارد يا خير؟ بنابراين، هدف از يروهش حاضر تأثير ده هفته تمرينات عضلات بردي

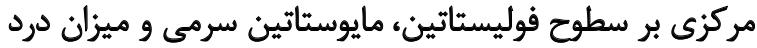

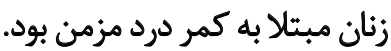

مواد وروشئها

اين تحقيق از نوع نيمهتجربى است بادو كروه آزمايش و كنترل

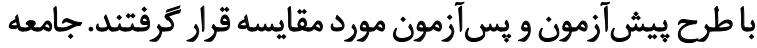

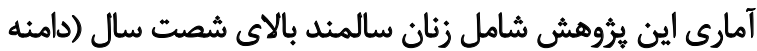

بنابراين مي توان كفت كاهش توده عضلانى طى روند سالمندى

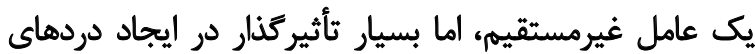

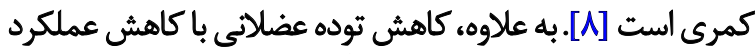

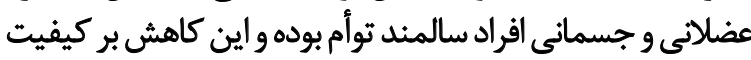

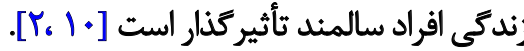

مايوستاتين نوعى فاكتور ترشحى و عضو خانواده بزرى

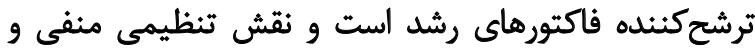

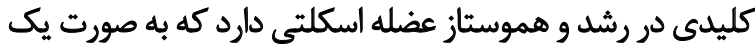

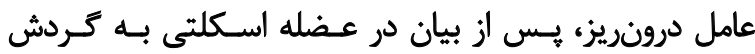
خون ترشح مىشود. مايوستاتين در سطح سلولهاى عضلانى با اتصال به كيرنده

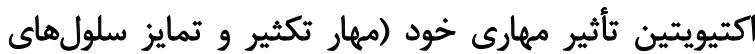

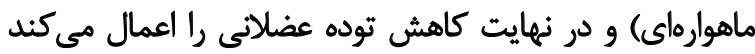

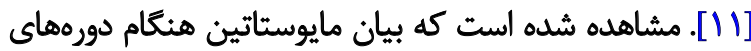

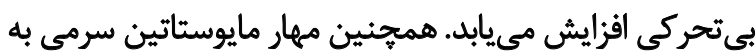

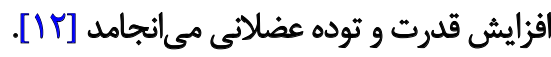

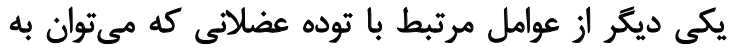

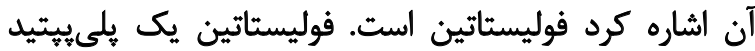

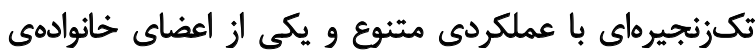

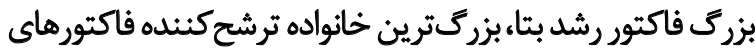
رشد، تمايز و هموستازى بدن است. اين خانواده نقشهاى بسيار مهمى رادر تنظيمي و بيشرفت رشد

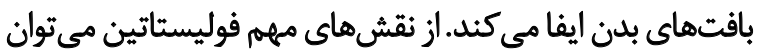

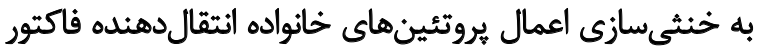

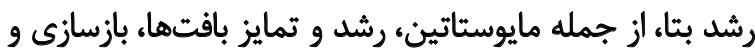

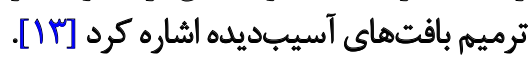

با توجه به نقش مهمي كه فوليستاتين و مايوستاتين در عضلات

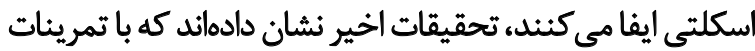

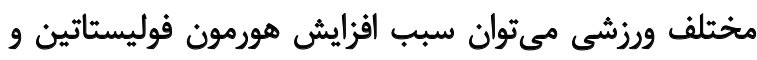

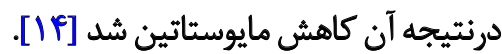

در اين زمينه، سانتوز' و همكاران با بررسى اثر هشت هفته

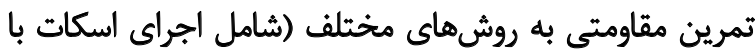

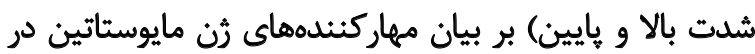

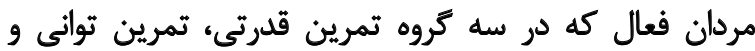

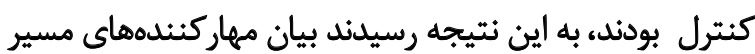

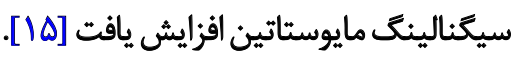
ياراحمدى و همكاران با بررسى اثربخشى تمرينات ثبات

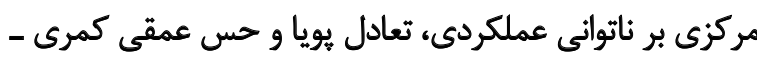

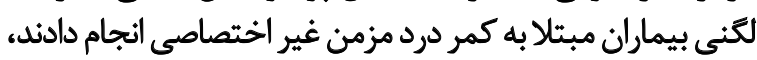

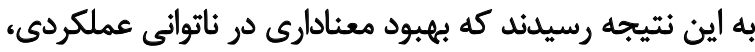

1. Santos 
از روى زمين، بلند شدن از روى تخت، خمم شدن به جلو و بلند

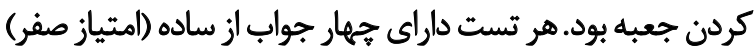

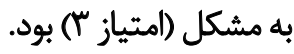

در تست جوراب يوشيدن، فرد روى نيمكت بلند طورى كه

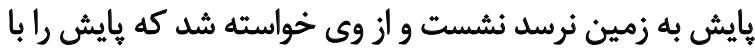

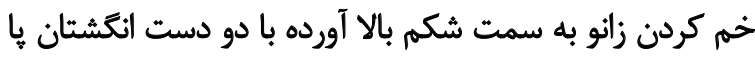

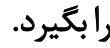

در تست برداشتن كاغذ از روى زمين، فرد در حالت ايستاده

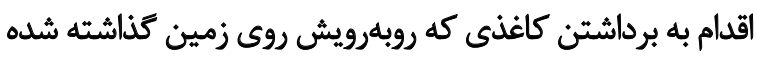

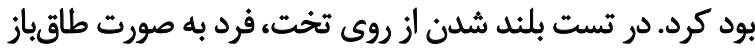

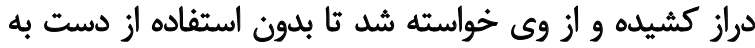

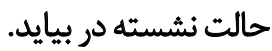

در تست خم شدن به جلو، فرد با زانوهاى صاف و فاصله دها

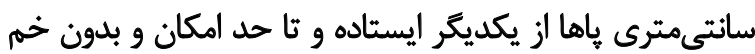

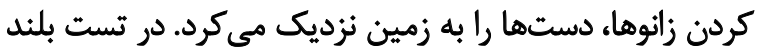

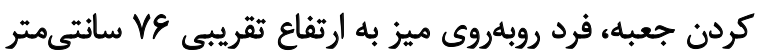

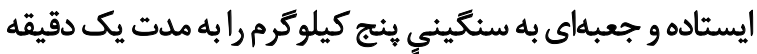

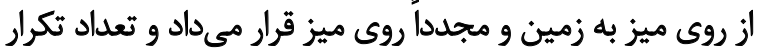

$$
\text { فرد ثبت مى ميز بهد. }
$$

حداكثر امتياز كسبشده معادل يانزده بوده و نمايانكر بدترين

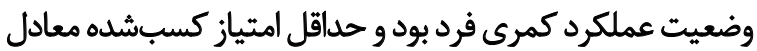
صفر بود كه نمايانكر بهترين وضعيت عملكرد بود حمد كمر بود.

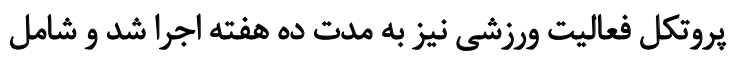

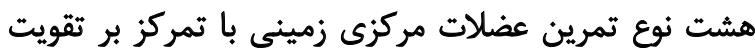

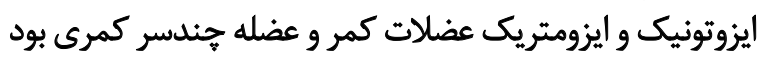

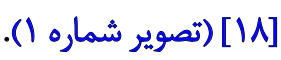

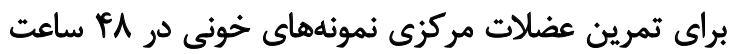

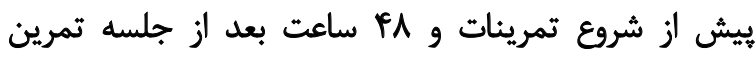

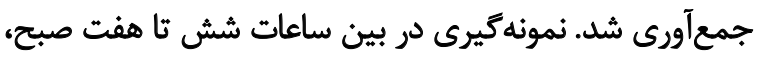

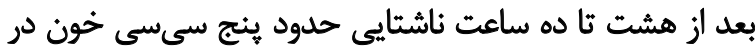

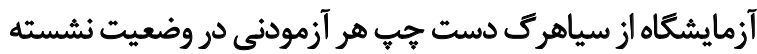
و در حالت استراحت أنجام شد.

براى تعيين ميزان فوليستاتين و مايوستاتين از روش الايزا

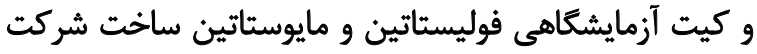
كازابايوى رُاين استفاده شد.

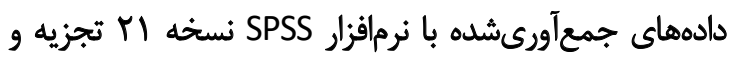

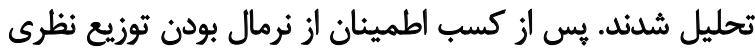

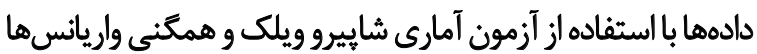
توسط آزمون لون از تى همبسته و آناليز كوواريانس (ANCOVA)

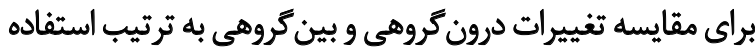

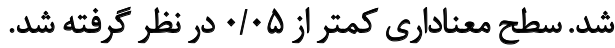

سنى بين شصت تا هفتاد سال) داراى كمر درد مزمن كه به روش

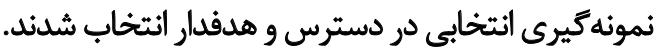
در مرحله نخست افراد با ماهيت و نحوه همكارى باريا اجراي

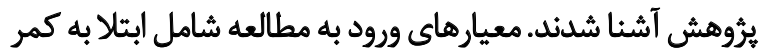

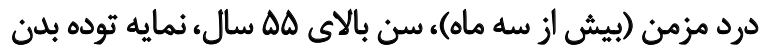

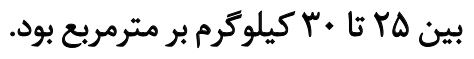

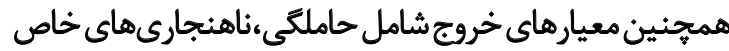

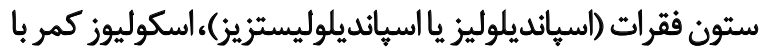

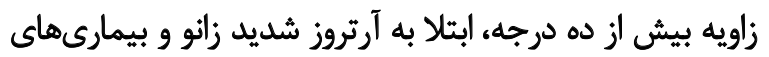

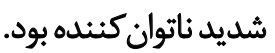

آزمودنىها بر اساس شرايط تحقيق به صورت داوطلبانه در

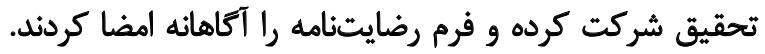

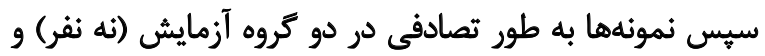
كنترل (نه نفر) دستلهبندى شدند.

براى ارزيابى تركيبات بدن به ترتيب قد آزمودنى ها با قدسنج

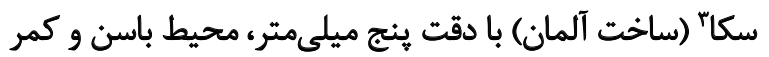

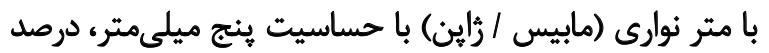

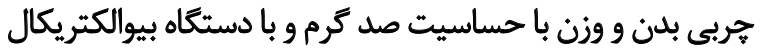

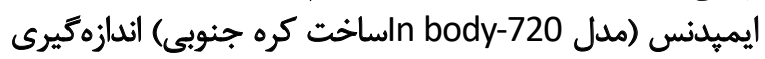

تمامى اندازهيرىها در حالى انجام شد كه آزمودنى ها از جهار

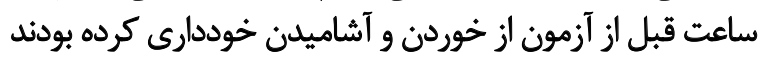

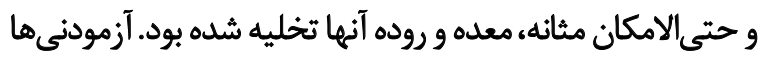

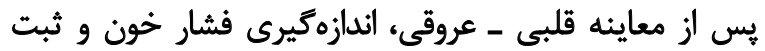

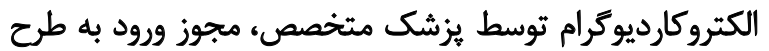

$$
\text { راكسب كردند. }
$$

در اين مطالعه، از نسخه عددى مقياس آنالوك بصرى (NAS)

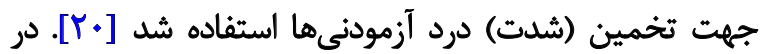

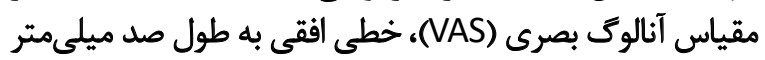

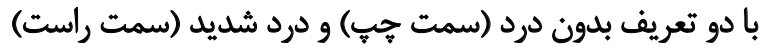

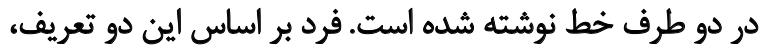
وضعيت درد خود را روى خط علامت مئ مئند. فرد براس

ميزان درد بر حسب ميلىمتر محاسبه مي شود. تفسير دادههاى

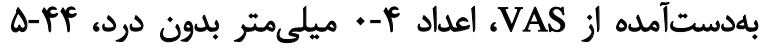
ميلى متر درد خفيف،

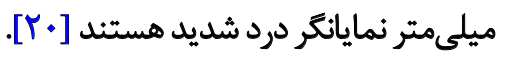

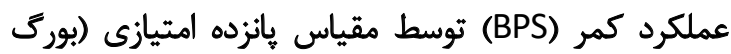

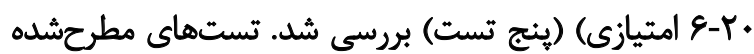

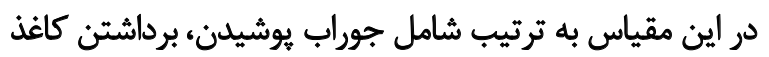



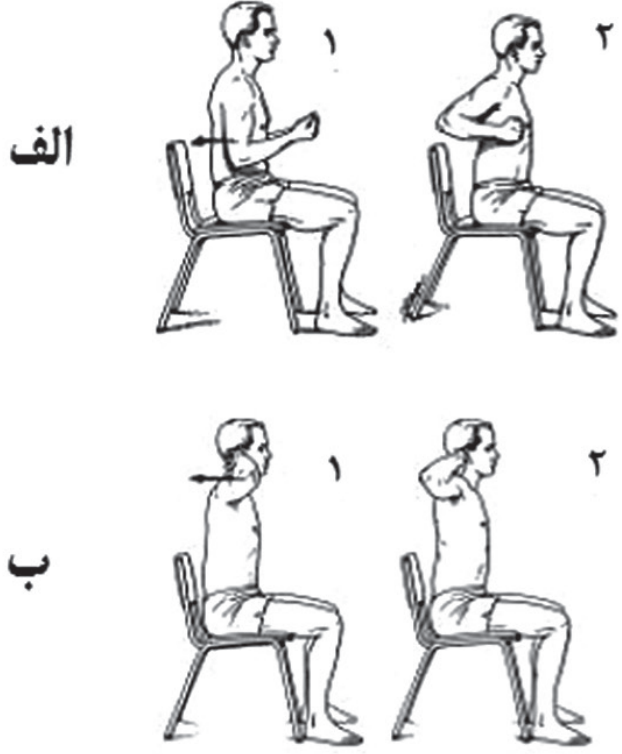

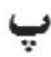
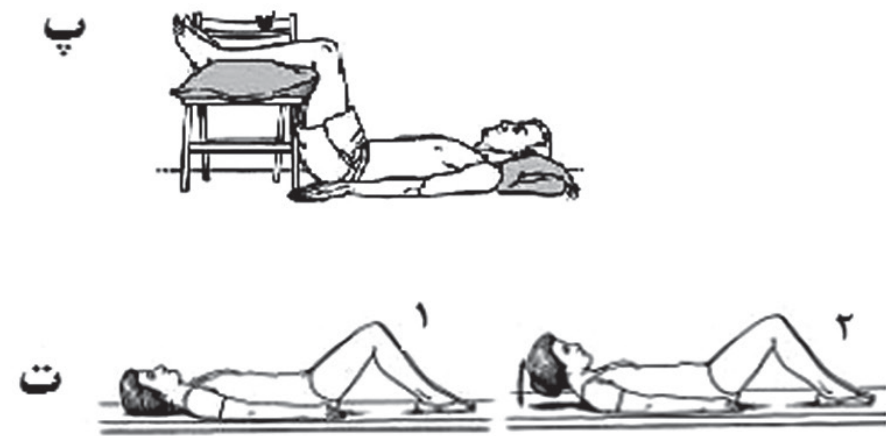

₹

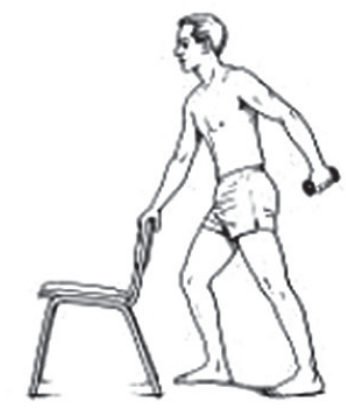

$\tau$
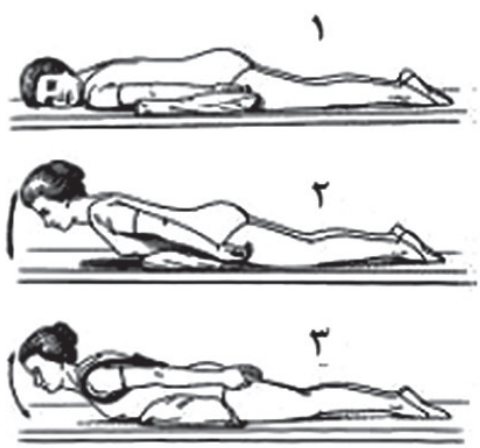

$\tau$

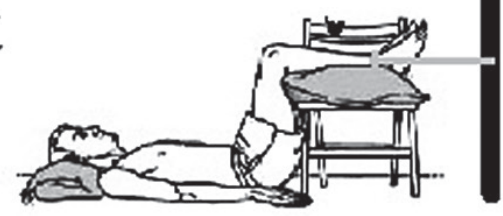

تصوير ا. تمرينات ثبات مركزى

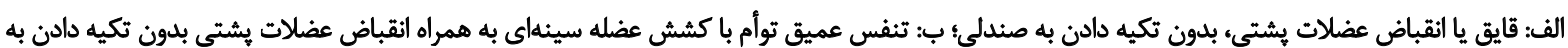

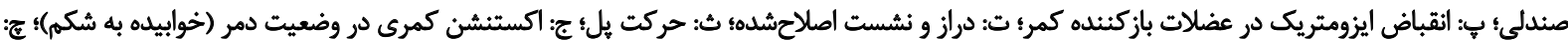

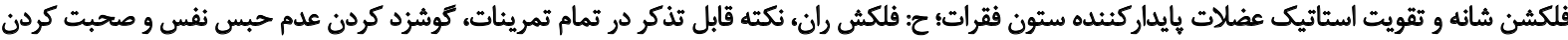

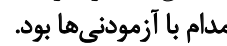

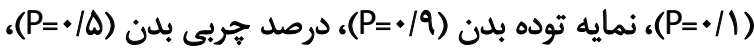

يافتهها

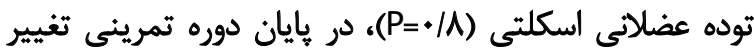

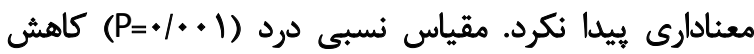
مشخصات آزمودنىهاى كروه آزمايش و كنترل در جدول

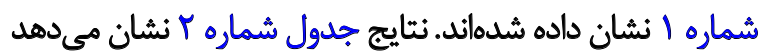

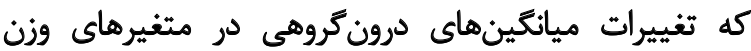


جدول ا. ويرّكى هاى آنترويومتريك زئان مبتلا به كمر درد مزمن

\begin{tabular}{|c|c|c|c|c|c|}
\hline \multicolumn{5}{|c|}{ متغير ها (انحراف معيار ثميائكين) } & \multirow{2}{*}{$\log 5$} \\
\hline درصد هربى بدن (درصد) & نمايه توده بدن (كيلوكَرم/مترمريع) & وزن (كيلوكّم) & قد (سانثى مثر) & سن (سال) & \\
\hline$\pi / A \pm N V$ & $r \Delta / q \pm F / A$ & $g g / r \pm F / \Delta r$ & $\mid q 1 / F \& \pm M / g F$ & SNATET/RT & تجربى (9 نفر) \\
\hline $\mathrm{m} / \Delta q \pm \Delta / \mathrm{s}$ & $r \Delta / \& A \pm r / \Delta r$ & $E g / \Delta q \pm r / M T$ & $|F| / Y \mid \pm Y / g r$ & $E q / \Delta P \pm r / A \Delta$ & كنترل (و نفر) \\
\hline
\end{tabular}

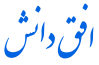

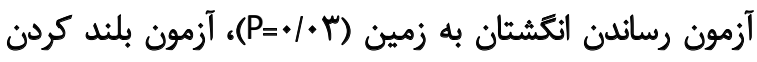

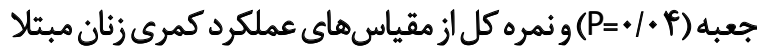

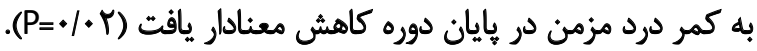

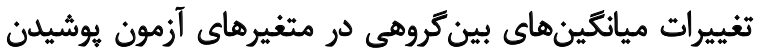

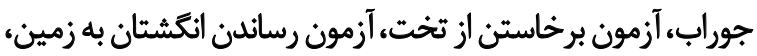

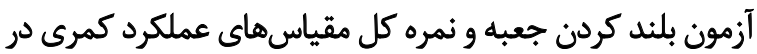

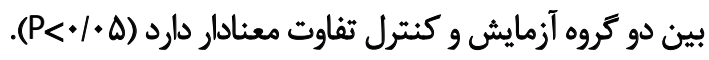

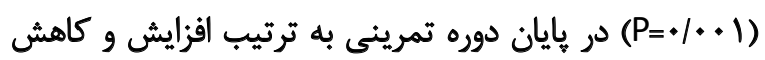

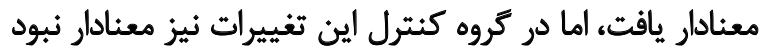

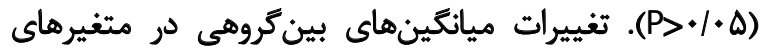

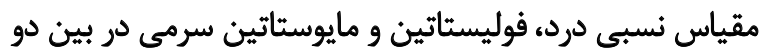

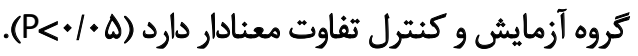
بر اساس نتايج جدول شماره ب، تغييرات ميانگينهاى

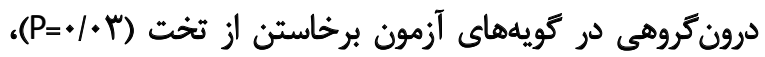

جدول با.تغييرات تركيب بدن، مقياس نسبى درد و سطوح فوليستائين و مايوستاتين زنان مبتلا به كمر درد مزمن

\begin{tabular}{|c|c|c|c|c|c|c|c|}
\hline \multicolumn{4}{|c|}{ تغييرات } & \multicolumn{2}{|c|}{ ميانيكين土 انحراف استانيدارد } & \multirow{3}{*}{ Sروهاه } & \multirow{3}{*}{ متغيرها } \\
\hline \multicolumn{2}{|c|}{ ينئكروه } & \multicolumn{2}{|c|}{ دون } & \multirow{2}{*}{ هسآزمون) } & \multirow{2}{*}{ ييش آزمون } & & \\
\hline $\mathbf{P}$ & $\mathbf{t}$ & $\mathbf{P}$ & $\mathbf{t}$ & & & & \\
\hline \multirow{3}{*}{./A\& } & \multirow{3}{*}{$\cdot / / V$} &.$/ 1$ & $1 / \cdot \cdot$ & $99 / 9 \Lambda \pm F / 9 r$ & $q \varphi / F \pm F / \Delta r$ & آزمايش & \multirow{3}{*}{ وزن (كيلوَّرم) } \\
\hline & & & & & & & \\
\hline & & $\cdot / 11$ & $1 / V V$ & $98 / 91 \pm 1 / \wedge V$ & $q q / \Delta q \pm r / r r$ & كنترل & \\
\hline \multirow[b]{2}{*}{.$/ 4$} & \multirow[b]{2}{*}{$-1 / r$} &.$/ 9$ & . /llf & $r \varepsilon / 1 \pm r / q$ & $r \Delta / \mathcal{\varepsilon} \pm F / \Lambda$ & آزمايش & \multirow{2}{*}{ 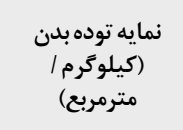 } \\
\hline & & .190 &.$/ 498$ & $r \Delta / \Delta q \pm r / r \digamma F$ & $r \Delta / \& \Lambda \pm r / \Delta r$ & كنترل & \\
\hline \multirow{2}{*}{$\cdot \mid \Delta s$} & \multirow{2}{*}{$r / \cdot$} & $\cdot / \Delta$ & .19 & $r r / .9 \pm \Lambda / F$ & $r r / \Lambda \pm \Lambda / V$ & آزمايش & \multirow{2}{*}{ 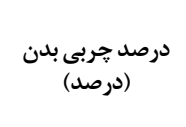 } \\
\hline & & $\cdot|\Delta|$ &.$- / 91$ & $r r / q \mu \pm \Delta / V$ & $r r / \Delta q \pm \Delta / \varphi$ & كنترل & \\
\hline \multirow{2}{*}{. } & \multirow{2}{*}{$1 / 10$} & .11 &.$/ 1$ & $\Upsilon q / \Upsilon \pm I / q \Lambda$ & $r \Lambda / r \varepsilon \pm r / q$ & آزمايش & \multirow{2}{*}{ اسكلتى (درصدى) } \\
\hline & &.$/ 19$ & $-\bullet / 14$ & $r \Lambda / I \pm r / r r$ & $r A / T r \pm T / r$ & كنترل & \\
\hline \multirow{2}{*}{...$r \dagger$} & \multirow{2}{*}{$-\mu / \nu$} &.$\cdot .1 \dagger$ & $-F / q$ & $r / Q T \pm r / Y F$ & $q / \Delta \pm \mid / r V \Lambda$ & 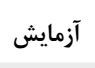 & \multirow{2}{*}{ مقياس نسبى درد } \\
\hline & & .119 & $-* / 1 f$ & $\varphi / \Delta V \pm \mid / \cdot$. & $q / r q \pm 1 / 11$ & 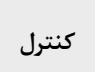 & \\
\hline \multirow{2}{*}{.$\cdot .1 \dagger$} & \multirow{2}{*}{$1 . / r T$} & $.1 . .1 \dagger$ & $\mid f / r$ & $q r / A \pm q / F$ & $r V / \Lambda \pm r / q$ & 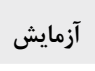 & \multirow{2}{*}{ فوليستاتين(نانوكرم } \\
\hline & & $\cdot|4|$ & $\cdot / \Lambda \Delta$ & $r \cdot / \Delta \pm V / r r$ & $r \Lambda / \pm \Delta / r$ & كنترل & \\
\hline \multirow{2}{*}{.. $.1 \dagger$} & \multirow{2}{*}{$p / 9 q$} & $.1 .01 \dagger$ & $\Delta / r$. & $r / \Delta r \pm . / r q$ & $F / \cdot F \pm \cdot / 1 \Delta$ & 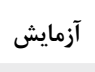 & \multirow{2}{*}{ (نانوكرم/ميلىليتيتر) } \\
\hline & & 政 & $-1 / \cdot \Delta$ & $r / / \omega \pm \cdot / r r$ & $\varphi / \cdot 9 \pm \cdot / 11$ & كنترل & \\
\hline
\end{tabular}


جدول r. مقايسه تغييرات واريانس درون كروهى و بين كروهى در خردهمقياس هاى عملكرد كمرى زنان مبتلا به كمر درد مزمن

\begin{tabular}{|c|c|c|c|c|c|c|c|}
\hline \multicolumn{4}{|c|}{ تغييرات } & \multicolumn{2}{|c|}{ ميانعين Iانحراف استاندارد } & \multirow{3}{*}{$\log _{0} 5$} & \multirow{3}{*}{ مثغيرها } \\
\hline \multicolumn{2}{|c|}{ بينكّوه } & \multicolumn{2}{|c|}{ درونكّوه } & \multirow{2}{*}{ هسأزمون } & \multirow{2}{*}{ بيشآزمون } & & \\
\hline $\mathbf{P}$ & $\mathbf{t}$ & $\mathbf{P}$ & $\mathbf{t}$ & & & & \\
\hline \multirow{2}{*}{$.1 .1 \dagger$} & \multirow{2}{*}{$-1 / \cdot \cdot$} & $\cdot 1 \cdot \Delta$ & $-r / Y q$ & I/IE॰/AT & $1 / \Delta \pm 1 / \cdot f$ & آزمايش & \multirow{2}{*}{ آزمون يوشيدن } \\
\hline & & . $/ v r$ & $-* / \% \Delta$ & 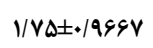 & $1 / \Delta \Delta \pm / 9 F$ & كنترل & \\
\hline \multirow{2}{*}{./Ir } & \multirow{2}{*}{ V/G4 } &.$/ 19$ & $-1 / 10$ & $1 / \cdot . \pm \cdot / 94$ & $1 / \Delta \pm \cdot / \Lambda$ & آزمايش & \multirow{2}{*}{ كاغذذاز برماشين } \\
\hline & &.$/ 19$ & $-1 / \Delta$ & $|/ \Delta \pm \cdot| \Delta \mid$ & $1 / F \Delta \pm+/ \varphi$ & كنترل & \\
\hline \multirow{2}{*}{.$/ .4 t$} & \multirow{2}{*}{$-r / \Delta F$} & $.1 .4 \dagger$ & $-\psi / T V$ & $1 / / V \pm 1 / 1$ & $r / / V \pm \cdot / q \Lambda$ & 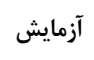 & \multirow{2}{*}{ آزمون برختاستن } \\
\hline & & . FF & $\cdot / 1$ & I/9 $\Delta \pm / \wedge r$ & $r / \cdot \pm * / V r \Delta$ & كنترل & \\
\hline \multirow{2}{*}{$.1 .+4$} & \multirow{2}{*}{$-r / 14$} & $.1 . r \dagger$ & $-F / r$ & $\cdot|\Lambda| \pm \cdot / 9 \mathrm{~V}$ & $1 / r \mu \pm 1 / \cdot \cdot$ & 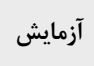 & \multirow{2}{*}{ آنكشتان به زمين } \\
\hline & & D & D/T/R & $|/ \cdot \Delta \pm \cdot| \Delta \mid$ & $1 / r \pm 1 / \cdot r 1$ & كنترل & \\
\hline \multirow[b]{2}{*}{$\cdot 1 \cdot r+$} & \multirow[b]{2}{*}{$-r / T \Delta$} & $.1 . \mathrm{pt}$ & $\varphi / .$. & $1 / \Delta \pm \cdot / \Delta F$ & $r / r r \pm \cdot|\Delta|$ & آزمايش & \multirow{2}{*}{ آزمون بلند كردن } \\
\hline & & $1 / \cdot \cdot$ & $\%$ & $r / r \Delta \pm \cdot / V \Lambda$ & $r / \mu_{ \pm} / \mathcal{F V}$ & كنترل & \\
\hline \multirow{3}{*}{.1 .11} & \multirow{3}{*}{$-r / 19$} &.$/ . r \dagger$ & $F / Q F$ & & $\Delta \Lambda / \Delta \pm 1 \Delta / q$ & آزمايش & \multirow{3}{*}{ نمره كل (درصد) } \\
\hline & & & & & & & \\
\hline & & $\cdot \mid \Delta \Delta$ &.$|9|$ & $\Delta \cdot / \Gamma \pm \Lambda / \Lambda$ & $\Delta r / r \pm 1 . / \bullet$ & كنترل & \\
\hline
\end{tabular}

أنّاتُ

$P<\cdot 1 \cdot \Delta$ ه

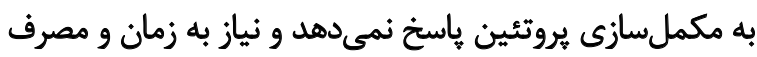

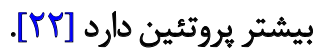

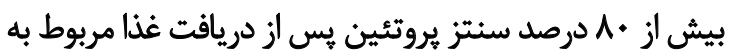

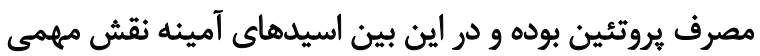

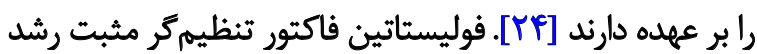

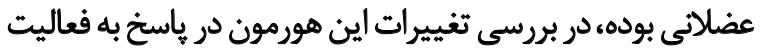

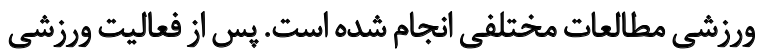

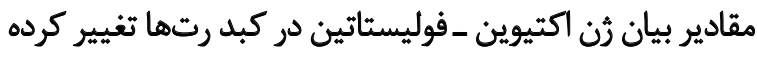
و سطوح mRNA اكتيوين كاهش مىيابد [Yه].

به طور كلى مطالعات كمى به بررسى ماركرهاي هاييرتروفي

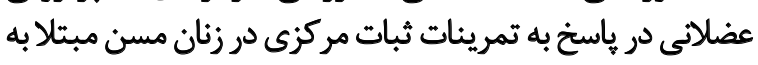

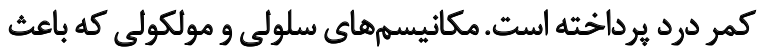

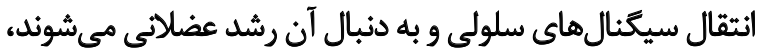
هنوز به طور دقيق شناخته نشدهاند.

انقباض عضلانى ناشى از فعاليت ورزشى، فرايند تبديل سيكنال مكانيكى به يك سلسله وقايع مولكولى است كها از طريق فيق

هدف از مطالعه حاضر بررسى تأثير ده هفته تمرينات عضلات

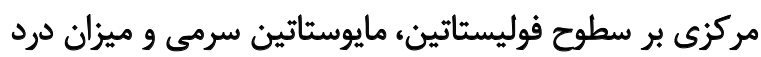
زنان مبتلا به كمر درد مزمن است.

نتايج تحقيق حاضر نشان داد كه تمرينات عضلات مركزي

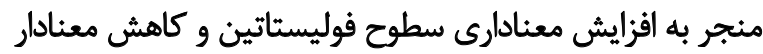

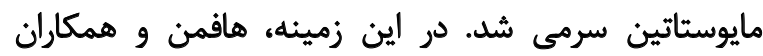

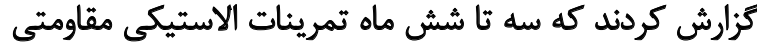

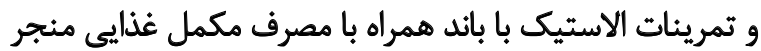

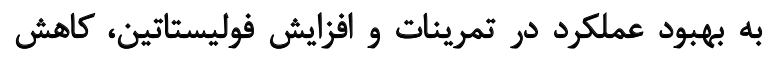

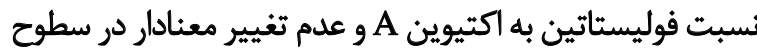

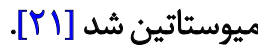

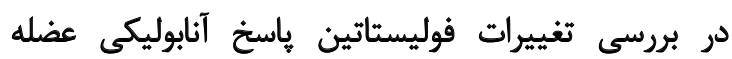

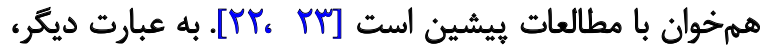

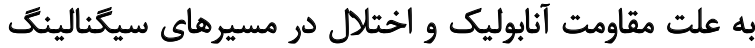
آنابوليكى عضله، عضله افراد مسن به خوبى آناوليك عضلات افراد جوان سينالين 


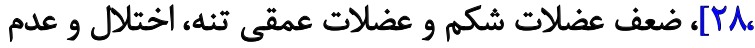

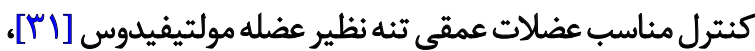
از جمله دلايل اصلي هستيند.

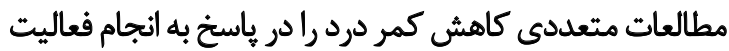

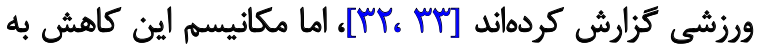

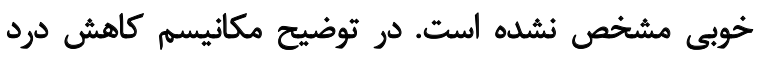

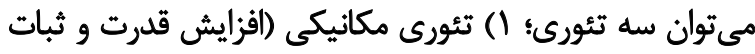

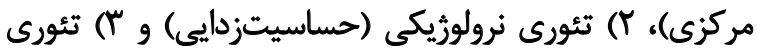

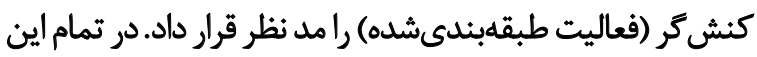

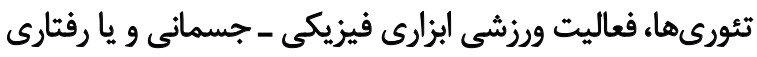

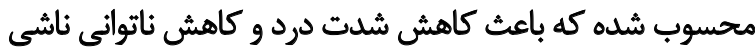

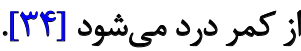

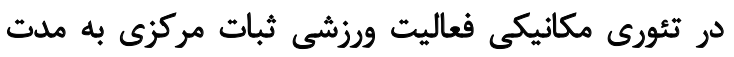

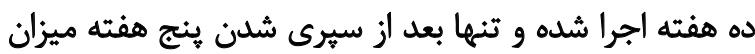

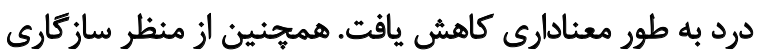

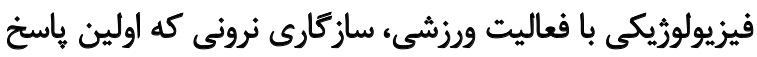

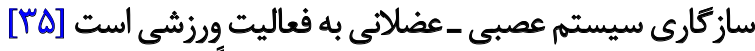

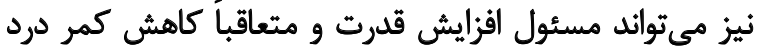

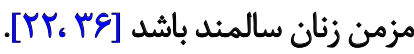

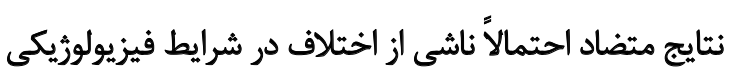

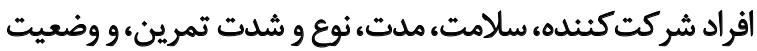

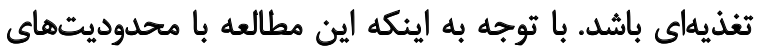

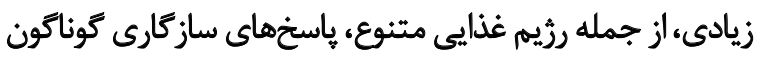

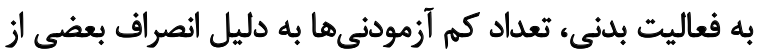

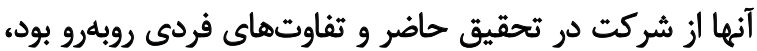
درنتيجه جانب احتياط را بيشتر بايد رعايت كرد ون فرات فردي

\section{تئيجليرى}

به طور كلى مى توان كفت كه تمرينات عضلات مركزى منجر

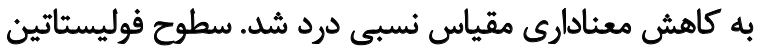

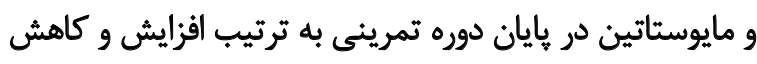

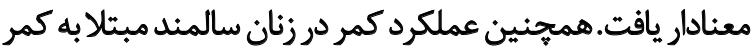
درد مزمن در يايان تمرين بهبود يافيون.

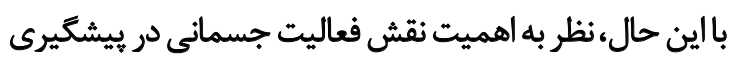

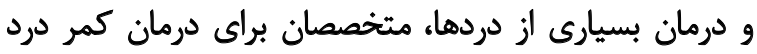

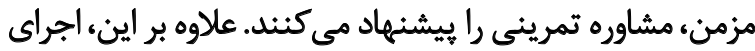

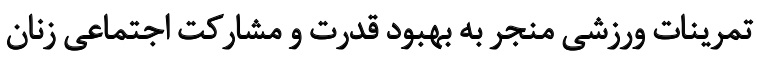

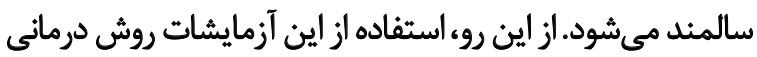

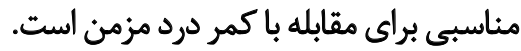

فعال سازى مسيرهاى سيكَنالى ويرٔه كه شامل بيامبرهاى اوليه و

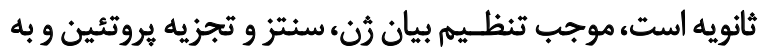

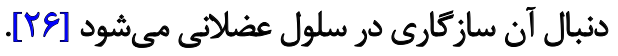

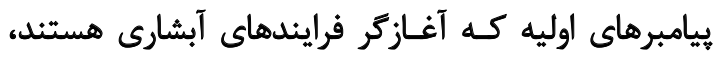

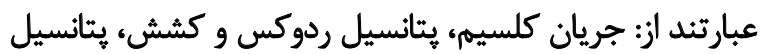

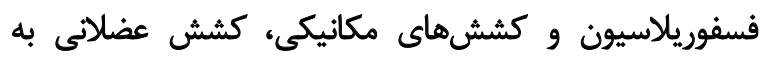

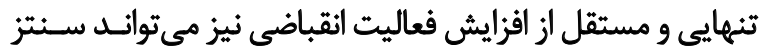

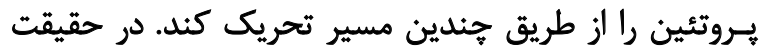

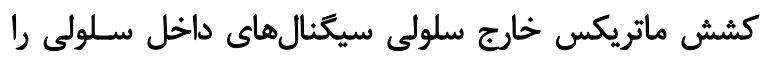

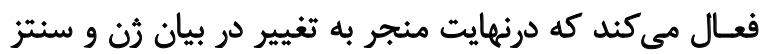
بروتئين مىشود [TV].

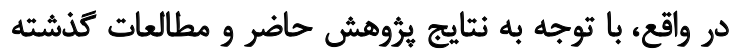

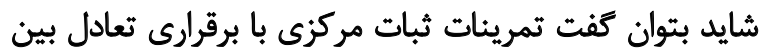

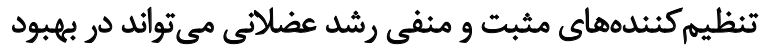

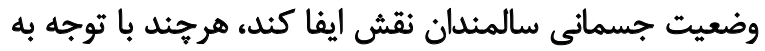

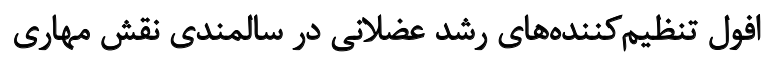

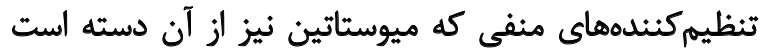
برجستهتر است [19]. البته اين نكته نيز قابل تأمل است كه افراد سالخورده به علت

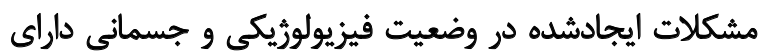

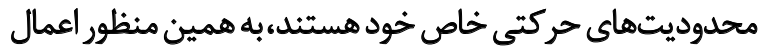

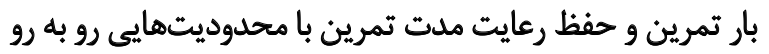

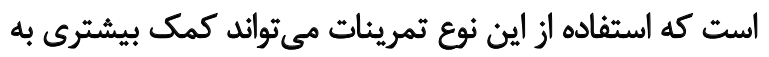

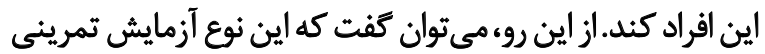

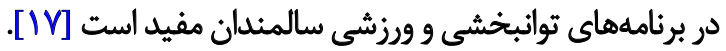
نتايج تحقيق حاضر نشان داد كه تمرينات ثبات مركزى

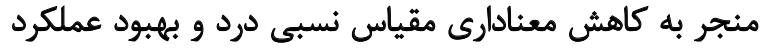

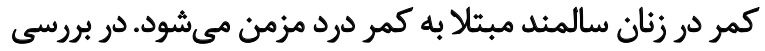

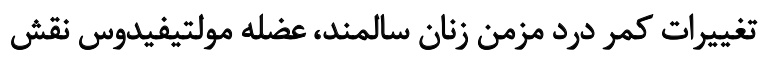

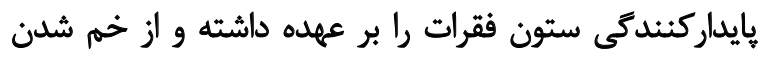

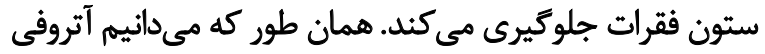

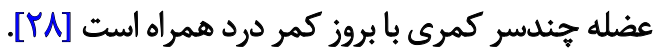
عضله مولتيفيدوس در موقعيت آناتوميكى محدودى قرار بر دارد. به طورى كه از طرفين توسط زوايد عرضى و شوكى موفى محصور

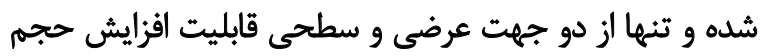

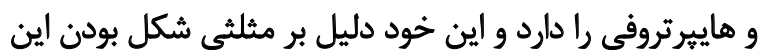

عضله است [Y [ب].

سطح مقطع عضله مولتيفيدوس با افزايش سن كاهش يافته و

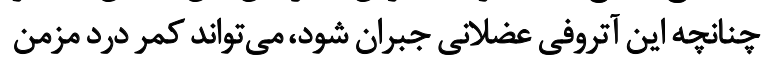

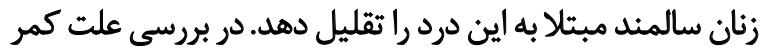

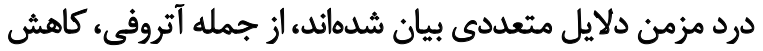

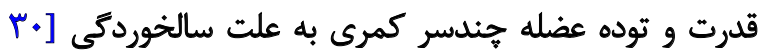




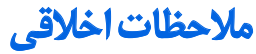

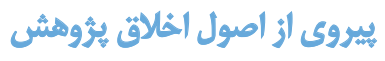

اين تحقيق در كميته اخلاق دانشكاه علوم يزشكى بجنورد با بإيا شماره مجوز IR.IAU.BOJNOURD.REC.1395.023 به تأييد

$$
\text { رسيده است مجوز }
$$

$$
\text { مامي مالى }
$$

اين مقاله از پاياننامه كارشناسى ارشد نويسنده اول، در كروه

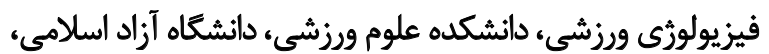

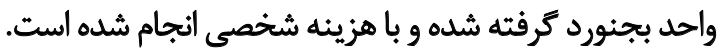




\section{References}

[1] Lynch GS. Sarcopenia-age-related muscle wasting and weakness: Mechanisms and treatments. Berlin: Springer Science \& Business Media; 2010. [DOI:10.1007/978-90-481-9713-2]

[2] Deschenes MR. Effects of aging on muscle fibre type and size. Sports Medicine (Auckland, NZ). 2004; 34(12):809-24. [DOI:10.2165/00007256200434120-00002] [PMID]

[3] Bales CW, Ritchie CS. Redefining nutritional frailty: Interventions for weight loss due to undernutrition. In: Bales CW, Ritchie CS, editors. Handbook of clinical nutrition and aging. New Jersey: Humana Press; 2009. [DOI:10.1007/978-1-60327-385-5_9]

[4] Sreeja V, Jana A, Aparnathi K, Prajapati J. Role of whey proteins in combating geriatric disorders. Journal of the Science of Food and Agriculture. 2013; 93(15):3662-9. [DOI:10.1002/jsfa.6345]

[5] Nedergaard A, Henriksen K, Karsdal MA, Christiansen C. Musculoskeletal ageing and primary prevention. Best Practice \& Research Clinical Obstetrics \& Gynaecology. 2013; 27(5):673-88. [DOI:10.1016/j.bpobgyn.2013.06.001] [PMID]

[6] Brown LA, Guzman SD, Brooks SV. Emerging Molecular Mediators and Targets for Age-related Skeletal Muscle Atrophy: Molecular targets involved in sarcopenia. Translational Research. 2020; 221:44-57. [DOI:10.1016/j.trsl.2020.03.001] [PMID]

[7] Ikezoe T, Mori N, Nakamura M, Ichihashi N. Effects of age and inactivity due to prolonged bed rest on atrophy of trunk muscles. European Journal of Applied Physiology. 2012; 112(1):43-8. [DOI:10.1007/s00421011-1952-x] [PMID]

[8] Angeletti C, Guetti C, Ursini ML, Taylor Jr R, Papola R, Petrucci E, et al. Low back pain in a natural disaster. Pain Practice. 2014; 14(2):E8-16. [DOI:10.1111/papr.12087] [PMID]

[9] Ikezoe T, Mori N, Nakamura M, Ichihashi N. Atrophy of the lower limbs in elderly women: Is it related to walking ability? European Journal of Applied Physiology. 2011; 111(6):989-95. [DOI:10.1007/s00421-0101728-8] [PMID]

[10] Beas-Jiménez JdD, López-Lluch G, Sánchez-Martínez I, Muro-Jiménez A, Rodríguez-Bies E, Navas P. Sarcopenia: Implications of physical exercise in its pathophysiology, prevention and treatment. Revista Andaluza de Medicina del Deporte. 2011; 4(4):158-66. https://www.elsevier.es/ es-revista-revista-andaluza-medicina-del-deporte-284-articulo-sarcopenia-implications-physical-exercise-in-X1888754611937888

[11] McFarland DC, Velleman SG, Pesall JE, Liu C. Effect of myostatin on turkey myogenic satellite cells and embryonic myoblasts. Comparative Biochemistry and Physiology Part A: Molecular \& Integrative Physiology. 2006; 144(4):501-8. [DOI:10.1016/j.cbpa.2006.04.020] [PMID]

[12] Eilers W, Chambers D, Cleasby M, Foster K. Local myostatin inhibition improves skeletal muscle glucose uptake in insulin resistant high fat dietfed mice. American Journal of Physiology-Endocrinology and Metabolism. 2020; 319(1):E163-74. [DOI:10.1152/ajpendo.00185.2019] [PMID]

[13] Attarzadeh Hosseini SR, Motahari Rad M, Hejazi K. Effects of Ramadan fasting and regular physical activity on serum myostatin and follistatin concentrations. International Journal of Applied Exercise Physiology. 2016; 5(3):38-45. https://www.academia.edu/31162506/Effects_of_ Ramadan_fasting_and_Regular_Physical_Activity_on_Serum_Myostatin_and_Follistatin_Concentrations

[14] Hittel DS, Axelson M, Sarna N, Shearer J, Huffman KM, Kraus WE. Myostatin decreases with aerobic exercise and associates with insulin resistance. Medicine and Science in Sports and Exercise. 2010; 42(11):2023-9. [DOI:10.1249/MSS.0b013e3181e0b9a8] [PMID] [PMCID]
[15] Santos AR, Lamas L, Ugrinowitsch C, Tricoli V, Miyabara EH, Soares AG, et al. Different resistance-training regimens evoked a similar increase in myostatin inhibitors expression. International Journal of Sports Medicine. 2015; 36(9):761-8. [DOI:10.1055/s-0035-1547219] [PMID]

[16] Yarahmadi Y, Hadadnezhad M, Shojaodins S. [The effect of Eight weeks core stabilization on functional disability, dynamic balance and proprioception lumbo pelvic of subject with non-specific chronic low back pain (Persian)]. Journal of Anesthesiology and Pain. 2017; 8(3):54-66. http:// jap.iums.ac.ir/article-1-5347-fa.html

[17] Puntumetakul R, Chalermsan R, Hlaing SS, Tapanya W, Saiklang P Boucaut R. The effect of core stabilization exercise on lumbar joint position sense in patients with subacute non-specific low back pain: $A$ randomized controlled trial. Journal of Physical Therapy Science. 2018; 30(11):1390-5. [DOI:10.1589/jpts.30.1390] [PMID] [PMCID]

[18] Rastegar MM M, Haghighi A, Askari R. [Effect of core stabilization exercise on the reduction of low back pain and ultrasonic changes of multifidus in aged-women with chronic low back pain (Persian)]. Anesthesiology and Pain. 2016; 7(2):62-74. http://jap.iums.ac.ir/article-1-5244-en. html

[19] Vatankhah-khozani S, Haghshenas R, Faramarzi M. [The effect of 8 weeks of elastic band resistance training on serum myostatin and body composition in elderly women (Persian)]. Journal of Sport Biosciences. 2018; 10(3):347-58. [doi: 10.22059/jsb.2018.261987.1296]

[20] Hawker GA, Mian S, Kendzerska T, French M. Measures of adult pain: Visual analog scale for pain (vas pain), numeric rating scale for pain (nrs pain), mcgill pain questionnaire (mpq), short-form mcgill pain questionnaire (sf-mpq), chronic pain grade scale (cpgs), short form-36 bodily pain scale (sf-36 bps), and measure of intermittent and constant osteoarthritis pain (icoap). Arthritis Care \& Research. 2011; 63(S11):S240-52. [DOI:10.1002/acr.20543] [PMID]

[21] Hofmann M, Schober-Halper B, Oesen S, Franzke B, Tschan H, Bachl $\mathrm{N}$, et al. Effects of elastic band resistance training and nutritional supplementation on muscle quality and circulating muscle growth and degradation factors of institutionalized elderly women: the Vienna Active Ageing Study (VAAS). European Journal of Applied Physiology. 2016; 116(5):885-97. [DOI:10.1007/s00421-016-3344-8] [PMID] [PMCID]

[22] Greig CA. Nutritional approaches to the management of sarcopenia. Nutrition Bulletin. 2013; 38(3):344-8. [DOI:10.1111/nbu.12046]

[23] Robinson S, Cooper C, Aihie Sayer A. Nutrition and sarcopenia: a review of the evidence and implications for preventive strategies. Journal of Aging Research. 2012; 2012:510801. [DOI:10.1155/2012/510801] [PMID] [PMCID]

[24] Kim JS, Wilson JM, Lee SR. Dietary implications on mechanisms of sarcopenia: Roles of protein, amino acids and antioxidants. The Journal of Nutritional Biochemistry. 2010; 21(1):1-13. [DOI:10.1021/bi00530a001] [PMID]

[25] Gholamnezhad Z, Mégarbane B, Rezaee R. Molecular mechanisms mediating adaptation to exercise. In: Xiao J, editors. Physical exercise for human health. Advances in Experimental Medicine and Biology (vol 1228). Singapore: Springer; 2020. [DOI:10.1007/978-981-15-1792-1_3] [PMID]

[26] Burkholder TJ. Mechanotransduction in skeletal muscle. Frontiers in Bioscience: A Journal and Virtual Library. 2007; 12:174-91. [DOI:10.2741/2057] [PMID] [PMCID]

[27] Egan B, Zierath JR. Exercise metabolism and the molecular regulation of skeletal muscle adaptation. Cell Metabolism. 2013; 17(2):162-84. [DOI:10.1016/j.cmet.2012.12.012] [PMID] 
[28] Freeman MD, Woodham MA, Woodham AW. The role of the lumbar multifidus in chronic low back pain: A review. PM \& R. 2010; 2(2):142-6. [DOI:10.1016/j.pmrj.2009.11.006] [PMID]

[29] Stokes M, Rankin G, Newham DJ. Ultrasound imaging of lumbar multifidus muscle: Normal reference ranges for measurements and practical guidance on the technique. Manual Therapy. 2005; 10(2):116-26. [DOI:10.1016/j.math.2004.08.013] [PMID]

[30] Cheung WK, Cheung JPY, Lee WN. Role of ultrasound in low back pain: A review. Ultrasound in Medicine \& Biology. 2020; 46(6):1344-58. [DOI:10.1016/j.ultrasmedbio.2020.02.004] [PMID]

[31] Chang WD, Lin HY, Lai PT. Core strength training for patients with chronic low back pain. Journal of Physical Therapy Science. 2015; 27(3):619-22. [DOI:10.1589/jpts.27.619] [PMID] [PMCID]

[32] Owen PJ, Miller CT, Rantalainen T, Simson KJ, Connell D, Hahne AJ, et al. Exercise for the intervertebral disc: A 6-month randomised controlled trial in chronic low back pain. European Spine Journal. 2020; 29:188799. [DOI:10.1007/s00586-020-06379-7] [PMID]

[33] Sipaviciene S, Kliziene I. Effect of different exercise programs on nonspecific chronic low back pain and disability in people who perform sedentary work. Clinical Biomechanics. 2020; 73(1):17-27. [DOI:10.1016/j. clinbiomech.2019.12.028] [PMID]

[34] Helmhout PH, Staal JB, Maher CG, Petersen T, Rainville J, Shaw WS. Exercise therapy and low back pain: Insights and proposals to improve the design, conduct, and reporting of clinical trials. Spine. 2008; 33(16):1782-8. [DOI:10.1097/BRS.0b013e31817b8fd6] [PMID]

[35] Kravitz L. Resistance training: Adaptations and health implications. Idea Today. 1996; 14:38-49. http://www.unm.edu/ Ikravitz/Article\%20 folder/resistben.html

[36] Kukuljan S, Nowson CA, Sanders K, Daly RM. Effects of resistance exercise and fortified milk on skeletal muscle mass, muscle size, and functional performance in middle-aged and older men: An 18-mo randomized controlled trial. Journal of Applied Physiology. 2009; 107(6):1864-73. [DOI:10.1152/japplphysiol.00392.2009] [PMID] 
This Page Intentionally Left Blank 